DOI: $10.33741 / 0435-1991.41 .18$

\title{
МОЛЕКУЛЯРНО-ГЕНЕТИЧНІ ОСОБЛИВОСТІ ПЕРЕБІГУ В-КЛІТИННОГО ХРОНІЧНОГО ЛІМФОЦИТАРНОГО ЛЕЙКОЗУ
}

\author{
Перехрестенко Т. П. ${ }^{1}$, Мельник У. І. ${ }^{2}$, Видиборець С. В. ${ }^{1}$ \\ ${ }^{I}$ Національний університет охорони здоров'я Украӥни ім. П.Л. Шупика, \\ Київ, Україна \\ ${ }^{2}$ КНП «Київська міська клінічна лікарня № 9», Київ, Украӥна
}

\begin{abstract}
Резюме
Вступ. На сьогоднішній день для формування прогнозу перебігу В-клітинного хронічного лімфолейкозу (В-ХЛЛ) необхідно визначати молекулярно-генетичні маркери. Наявність хромосомих аномалій сприятливого та несприятливого прогностичного значення дозволяють формувати план курації паџієнтів. У статті наведено результати власних досліджень з вивчення делеціï 13q14, 11q23 та трисомії хромосоми 12 та надано клінічну характеристику пацієнтів відповідно до ӥхніх генетичних ознак.
\end{abstract}

Мета. Визначити зв'язок генетичних даних із клінічними характеристиками BХЛЛ.

Матеріали і методи. У дослідженні брали участь 37 хворих на В-ХЛЛ, класифікованих за Rai et al. Діагноз В-ХЛЛ встановлювали з урахуванням клінічних даних, результатів дослідження периферичної крові, імунофенотипу клітин. Групу склали 23 чоловіка, 14 жінок (1,6:1). Вік хворих коливався в межах від 33 до 73 років. Маркерами для постановки діагнозу В-ХЛЛ були експресія $C D 5^{+,} C D 10^{-}, C D 23^{+}{ }^{3}$ коекспресією CD19, CD20 та експресією Ig в мономорфній популячії малих лімфочитів. Вивчення цитогенетичних аберацій проводилося за допомогою FISH-методу.

Результати. Делеція 13q14 визначалася у 23 пацієнтів, щуо склало 63 \%. Клінічний перебіг захворювання у даних пацієнтів не відрізнявся від пацієнтів із нормальним каріотипом. Час до ініціації терапії статистично не різнився в обох групах $i$ складав (13,5 \pm 5,1) міс. та (14,6 \pm 5,2) міс., відповідно. Ми не отримали статистично достовірних відмінностей у часі до прогресії захворювання у хворих з нормальним каріотипом і хворих з делецією 13q14. У той же час в нашому дослідженні було отримано відмінності в перебігу В-ХЛЛ з делецією $11 q 23 i$ трисомією хромосоми 12 з достовірно більш тривалим часом до прогресіі захворювання у групі з трисомією хромосоми 12 порівняно з делецією 11q23. Слід зазначити, що у пацієнтів з делечією 11q23 спостерігалася характерна клінічна особливість, так звана пухлинна форма В-ХЛЛ.

Висновки. Молекулярно-генетичні маркери $є$ незалежними прогностичними чинниками перебігу B-ХЛЛ, котрі необхідно досліджувати через їх вплив на перебіг захворювання. 
Ключові слова: В-ХЛЛ, хромосомні аберащіï, делеція 13q14, делеція 11q23, трисомія хромосоми 12.

Конфлікт інтересів: автори заявляють про відсутність конфлікту інтересів.

Фінансування: дослідження не мало спонсорської підтримки.

\title{
MOLECULAR FEATURES \\ OF B-CELL CHRONIC LYMPHOID LEUKEMIA
}

\author{
Perekhrestenko T. P. ${ }^{1}$, Melnyk U. I. ${ }^{2}$, Vydyborets S. V. ${ }^{1}$ \\ ${ }^{1}$ Shupyk National Healthcare University of Ukraine, Kyiv, Ukraine \\ ${ }^{2}$ CNE «Kyiv City Clinical Hospital № 9», Kyiv, Ukraine
}

\begin{abstract}
Introduction. To date, molecular genetic markers need to be determined to predict the prognosis of B-cell chronic lymphocytic leukemia. The presence of chromosomal abnormalities of favorable and unfavorable prognostic value allows to form a plan of supervision of patients. The article presents the results of our own research on the study of deletions 13q14, 11q23 and trisomy of chromosome 12 and provides clinical characteristics of patients according to their genetic characteristics.

Aim. To determine the relationship of genetic data with the clinical characteristics of $B$ CLL.

Materials and methods. We included 37 CLL patients in study, classified by Rai et al. The study involved 23 men and 14 women (1.6: 1). The age of patients ranged from 33 to 73 years. Markers for the diagnosis of $B-C L L$ were the expression of $C D 5^{+,} C D 10^{-}$, $C D 23^{+}$with coexpression of CD19, CD20 and Ig expression in a monomorphic population of small lymphocytes. The study of cytogenetic aberrations was performed using the Fluorescence in situ hybridization (FISH).

Results. Deletion of 13 q14 was detected in 23 patients, which was $63 \%$. The clinical course of the disease in these patients did not differ from patients with a normal karyotype. The time to initiation of therapy did not differ statistically in both groups and was $(13.5 \pm 5.1)$ months and $(14.6 \pm 5.2)$ months, respectively. We did not find statistically significant differences in time to disease progression in patients with normal karyotype and patients with deletion of 13q14. At the same time, our study showed differences in the course of B-CLL with deletion of 11 q23 and trisomy of chromosome 12 with a significantly longer time to disease progression in the group with trisomy of chromosome 12 compared with deletion of 11q23. It should be noted that patients with a deletion of 11q23 had a characteristic clinical feature, the so-called tumor form of BCLL. Regarding the presence of trisomy 12 in CLL patients, it should be noted that this study did not show an increase in the incidence of secondary neoplasms in patients. We also did not observe the transformation of B-CLL into Richter's syndrome.
\end{abstract}


Conclusions. Molecular genetic markers are independent prognostic factors in the course of B-CLL, which need to be studied because of their influence on the course of the disease.

Keywords: B-CLL, chromosomal aberrations, $13 q 14$ deletion, $11 q 23$ deletion, trisomy 12.

\section{Вступ}

Хронічний В-клітинний лімфолейкоз (В-ХЛЛ) - злоякісне захворювання, що характеризується клональною проліферацією і накопиченням пухлинних CD5, CD23-позитивних В-клітин в кістковому мозку, периферичній крові, лімфатичних вузлах і селезінці. Дане захворювання становить 25 \% всіх лейкозів дорослих і 40 \% всіх лейкозів у хворих старше 65 років. Ризик виникнення В-ХЛЛ збільшується 3 віком, медіана віку хворих становить 65 років [1]. Чоловіки хворіють удвічі частіше за жінок [2]. Клінічні прояви і прогноз при В-ХЛЛ дуже гетерогенні. Деякі хворі живуть 20 і більше років, не потребуючи терапії, в той час як у інших прогресія пухлини протягом декількох місяців вимагає початку лікування [3]. Традиційно перебіг В-ХЛЛ поділяється на початкову стадію, під час якої здійснюється лише спостереження за перебігом захворювання, i стадію розгорнутих клінічних проявів, коли з'являється необхідність починати терапію [4]. В останні роки були розроблені методи терапії ВХЛЛ, такі як терапія моноклональними антитілами, малими молекулами, що сприяють покращенню результатів лікування. Ці терапевтичні підходи помітно відрізняються від існуючих раніше щодо ефективності, токсичності та вартості [5]. Відповідно змінюються мета і задачі при розробці схем терапії В-ХЛЛ. На зміну традиційній тактиці приходить ризикадаптована терапія. Класичні або динамічні маркери прогнозу - стадія захворювання, тип інфільтрації кісткового мозку, час подвоєння лімфоцитів, рівні лактатдегідрогенази (ЛДГ), розчинного CD23, $\beta 2$-мікроглобуліну - корелюють з масою пухлини і змінюються з часом. Генетичні маркери - мутаційний статус генів варіабельного регіону імуноглобулінів (VH) i цитогенетичні аберації - можуть бути визначені вже в дебюті хвороби, коли ще немає жодних клінічних показань до початку лікування, i тому вони $є$ найбільш цінними чинниками прогнозу для В-ХЛЛ [6]. Розширення знань про патогенез захворювання з боку виникнення певних генетичних аберацій повністю змінює підходи до визначення груп прогностичного ризику, більш того вимагає обов'язкового їх виконання через необхідність застосовувати абсолютно інші терапевтичні підходи. На сьогоднішній день в Україні існує проблема обмеженого проведення генетичних досліджень, що значно знижує якість діагностики. У нашій 
роботі ми висвітлимо деякі генетичні зміни при В-ХЛЛ, котрі найчастіше зустрічаються при даному захворюванні, та продемонструємо їхній вплив на перебіг В-ХЛЛ.

Метою нашої роботи було визначити зв'язок генетичних даних із клінічними характеристиками В-ХЛЛ.

\section{Матеріали і методи}

Спостерігали 37 хворих на В-ХЛЛ, класифікованих за Rai et al. Діагноз В-ХЛЛ встановлювали з урахуванням клінічних даних, результатів дослідження периферичної крові, імунофенотипу клітин. Групу склали 23 чоловіки, 14 жінок $(1,6: 1)$. Вік хворих коливався в межах від 33 до 73 років. Пацієнти в залежності від віку були розподілені відповідно до міжнародної класифікації на 3 групи: 1-а - молодого віку (від 30 до 44 років), 2-а - зрілого (від 45 до 59 років), 3-я -похилого (від 60 до 74 років). У 1-у групу увійшли 8 пацієнтів (21\%), 2-у - 17 (46 \%), у 3-ю - 12 хворих (32\%). Серед пацієнтів з В-ХЛЛ переважали особи зрілого віку.

Стадія захворювання визначалася за класифікацією за Rai et al:

Стадія 0: лімфоцитом $>15,0 \times 10^{9} /$ л в крові $\mathrm{i}>30 \%$ лімфоцитів в кістковому мозку (КМ).

Стадія I: лімфоцитоз і збільшення лімфовузлів у 1-2 областях.

Стадія II: лімфоцитоз і гепато- або спленомегалія незалежно від збільшення лімфовузлів.

Стадія III: лімфоцитоз і зниження рівня Нв нижче 110 г/л незалежно від збільшення лімфовузлів і органів.

Стадія IV: лімфоцитоз і зниження кількості тромбоцитів нижче $100,0 \times 10^{9} /$ л незалежно від збільшення лімфовузлів і органів.

На момент дослідження у стадії II знаходилося 12 пацієнтів, у стадії III - 18 та у стадії IV -7.

Ключовими маркерами для постановки діагнозу В-ХЛЛ були експресія $\mathrm{CD}^{+}, \mathrm{CD} 10^{-}, \mathrm{CD} 23^{+}$з коекспресією CD19, CD20 та експресією Ig в мономорфній популяції малих лімфоцитів.

У нашому дослідженні хромосомні порушення досліджувалися за допомогою флуоресцентної гібридизації in situ (fluorescence in situ hybridization - FISH) периферичної крові з ДНК-зондами для виявлення делеції хромосоми 11, хромосоми 13 та трисомії хромосоми 12. Молекулярногенетичні дослідження виконувалися у лабораторії ТОВ «ІММД», НУОЗ імені П. Л. Шупика (кафедра клінічної лабораторної діагностики). Медіана спостереження за хворими склала 29 місяців. Оцінку статистично значимих відмінностей середніх значень кількісних ознак, що підлягали 
нормальному закону розподілу, у незалежних групах визначали за допомогою t-критерія Стьюдента. Усі пацієнти надали інформовану згоду на використання персональних даних.

\section{Результати та їх обговорення}

При проведенні даного дослідження делеція 13q14 визначалася у 23 пацієнтів, що склало 63 \%. Такі дані співставні з результатами досліджень інших авторів [3, 5]. Клінічний перебіг захворювання у даних пацієнтів не відрізнявся від пацієнтів із нормальним каріотипом. Час до ініціації терапії статистично не різнився в обох групах і складав $(13,5 \pm 5,1)$ міс. та $(14,6 \pm 5,2)$ міс., відповідно. Ми не отримали статистично достовірних відмінностей у часі до прогресії захворювання у хворих 3 нормальним каріотипом i хворих 3 делецією 13q14. Після першої лінії терапії із застосуванням режимів BR (бендамустин+ритуксимаб) та FCR (флударабін+циклофосфамід+ритуксимаб) рецидив захворювання у двох групах відбувся відповідно через $(24,6 \pm 6,8)$ міс. та $(28,3 \pm 5,5)$ міс.

У той же час були встановлені відмінності в перебігу В-ХЛЛ 3 делецією 11q23 і трисомією хромосоми 123 достовірно більш тривалим часом до прогресії захворювання у групі 3 трисомією хромосоми 12 порівняно $з$ делецією 11q23. Так, у пацієнтів з наявністю трисомії 12, в середньому, спостерігалась прогресія захворювання через $(15,3 \pm 3,5)$ міс., натомість у пацієнтів 3 делецією 11q23 рецидив констатувався протягом, в середньому, $(8,4 \pm 3,5)$ міс. Слід зазначити, що у пацієнтів 3 делецією 11q23 спостерігалася характерна клінічна особливість у вигляді генералізованої лімфаденопатії з формуванням великих конгломератів периферичних, внутрішньогрудних і абдомінальних лімфовузлів, тобто у даних пацієнтів виявлялася пухлинна форма В-ХЛЛ. У нашій роботі було виявлено, що пухлинна форма В-ХЛЛ характеризується наступними цитогенетичними особливостями: делеція 11q23 виявляється в більшості випадків, а саме у 62 \% пацієнтів зі збільшеною пухлинною масою, трисомія хромосоми 12 - достовірно частіше, ніж при інших формах В-ХЛЛ, a саме у 24 \% пацієнтів, і делеція $13 q 14$ - ніколи, незважаючи на те, що дана аберація найчастіше зустрічається при В-ХЛЛ. Таким чином, у нас є підстави вважати, що пухлинна форма В-ХЛЛ є чітко окресленим у цитогенетичному плані захворюванням, і наявність делеції 11q23 - його головна, але не строго обов'язкова ознака [7]. Наші дані узгоджуються 3 результатами інших дослідників [8-10]. Щодо наявності у пацієнтів трисомії хромосоми 12 слід зазначити, що під час даного дослідження не виявлено збільшення частоти вторинних неоплазій у пацієнтів. Також ми 
не спостерігали трансформацію В-ХЛЛ у синдром Ріхтера. Такі особливості притаманні для пацієнтів з трисомією хромосоми 12 [11].

У таблиці наведено клініко-лабораторні показники пацієнтів з В-ХЛЛ відповідно до їхніх генетичних характеристик (табл. 1).

\section{Таблиця 1. Клініко-лабораторні показники паціснтів з В-ХЛЛ з різними генетичними аномаліями}

\begin{tabular}{|l|c|c|c|c|}
\hline \multicolumn{2}{|c|}{ Показники } & del 13q & $\mathbf{+ 1 2}$ & del 11q \\
\hline \multirow{2}{*}{$\begin{array}{c}\text { Вік на момент } \\
\text { встановлення діагнозу }\end{array}$} & $\begin{array}{c}\text { Медіана віку, } \\
\text { роки }\end{array}$ & $\mathbf{5 5}$ & $\mathbf{5 9}$ & $\mathbf{6 1}$ \\
\hline \multirow{2}{*}{ Стать } & Чоловіки, \% & 80 & 75 & 90 \\
\cline { 2 - 5 } Стадія Rаі & Жінки, \% & 20 & 25 & 10 \\
\hline Лейкоцитоз & $0-2, \mathrm{n}$ & 7 & 3 & 2 \\
\hline Пролімфоцити & $3-4, \mathrm{n}$ & 12 & 9 & 4 \\
\hline \multirow{2}{*}{ Бета-2- мікроглобулін } & Медіана, 10\%/л & 111 & 76 & 57 \\
\hline \multirow{2}{*}{ Імунофенотип } & Медіана, \% ПК & 5 & 6 & 3 \\
\cline { 2 - 5 } & $\leq 4$ мг/л, \% & 77 & 80 & 60 \\
\cline { 2 - 5 } & $>4$ мг/л, \% & 23 & 20 & 40 \\
\cline { 2 - 5 } & Типовий, \% & 11 & 55 & 30 \\
\hline
\end{tabular}

У 1980-х роках з'явилися перші публікації про цитогенетичні порушення при В-ХЛЛ. Виявлення аберацій було утруднено у зв'язку з вкрай низькою мітотичною активністю зрілих В-лімфоцитів - субстрату пухлини. Застосування В-клітинних мітогенів лише трохи збільшує кількість клітин, які діляться [7]. Препарати метафазних хромосом пухлинних клітин при В-ХЛЛ мають, зазвичай, незадовільну якість, внаслідок чого ідентифікація порушень каріотипу утруднена [8]. Крім того, нормальний каріотип, котрий часто виявляються при В-ХЛЛ, може бути представлений залишковою популяцією непухлинних Т-лімфоцитів [9]. Тим не менш, за допомогою стандартного цитогенетичного дослідження були виявлені аберації, які найбільш часто зустрічаються при В-ХЛЛ: делеції 13q14, 11q22-23, 17p13, 6q21 і трисомія хромосоми 12 [7]. Застосування флуоресцентної гібридизації in situ (FISH) при використанні зондів до локусів, в яких зустрічались характерні аберації при В-ХЛЛ, дозволило виявляти цитогенетичні порушення в інтерфазних ядрах пухлинних клітин приблизно у 55-80 \% хворих на В-ХЛЛ [6]. В основному, цитогенетичні порушення були визначені FISH-методом, однак проведення стандартного цитогенетичного дослідження вважається необхідним, 
оскільки ряд цитогенетичних порушень може бути виявлено тільки при цьому дослідженні, частіше за все - в складі комплексного каріотипу [7].

Делеція $13 q 14 \epsilon$ найчастішим структурним хромосомним порушенням, що виявляється при цитогенетичних дослідженнях при В-ХЛЛ [3]. Частота виявлення цієї аномалії за допомогою FISH коливається в межах 50$65 \%[3,7]$. Першим визначеним кандидатом tumor-супресорних геномів в локусі 13q14 виявився ген ретинобластоми. М. Fitchett визначив, що локалізація мінімальної ділянки делеції 13q14 близька до місця розташування гена ретинобластоми RB-1, i дане спостереження було підтверджено в подальших дослідженнях [12]. Делеція алелі гена RB1 була виявлена у чверті хворих на В-ХЛЛ, але інактивація обох алелей у результаті делеції або мутації визначається дуже рідко. 3 метою визначення нових tumor-супресорних генів при В-ХЛЛ різними дослідницькими групами була проведена повна розшифровка нуклеотидної послідовності тієї ділянки регіону $13 q 14$, який завжди делетується, i побудовані його генетичні карти [13-15]. Були визначені ймовірні tumorсупресорні гени. Однак, питання, який саме tumor-супресорний ген в регіоні бере участь в патогенезі В-ХЛЛ, залишається відкритим. Можливо, при даній делеції може бути задіяно більше одного гена в регіоні $13 q$ або доступні в даний час технології недостатньо чутливі, щоб визначити подібний ген [16]. 3 клінічної точки зору В-ХЛЛ з єдиною аберацією - делецією 13q14 - характеризується сприятливим перебігом захворювання. G. Juliusson і співавт. з'ясували, що у хворих з нормальним каріотипом або єдиною делецією 13q прогноз кращий, ніж у пацієнтів 3 трисомією хромосоми 12 , як єдиним цитогенетичним порушенням, або 3 комплексними порушеннями каріотипу [17]. Пізніше H. Dohner i співавт. [18] виявили, що медіана виживаності і час до необхідності починати лікування у хворих з єдиною делецією 13q14 більше, ніж при будь-якій іншій аберації і навіть при нормальному каріотипі. У хворих з єдиною делецією 13q значно частіше виявляється мутований варіант генів $\mathrm{VH}$, таким чином, ці 2 генетичних прогностичних чинника корелюють один 3 одним. Відомо, що випадки з мутованими генами VH характеризуються достовірно повільнішою прогресією пухлини і більш високою виживаністю хворих $[11,12]$. За даними дослідження G. Dewald і співавт. [3] єдина делеція 13q достовірно частіше зустрічається у хворих з низьким рівнем експресії CD38. Вона виявлялася тільки у хворих 3 ранніми стадіями В-ХЛЛ. Навпаки, поєднання делеції 13q14 з іншими аберацією характерно для хворих на пізніх етапах розвитку пухлини [10]. При поєднанні делеції 13q14 з тією чи іншою аберацією вона перестає бути 
маркером сприятливого прогнозу при В-ХЛЛ. Сприятливий прогноз підгрупи хворих В-ХЛЛ з єдиною делецією 13q14, скоріш за все, пов'язаний 3 тим, що ця делеція не прискорює прогресію захворювання [12].

Трисомія 12 була описана на початку 1980-х років до ери FISH як перша періодична аберація при В-ХЛЛ; за допомогою стандартного цитогенетичного дослідження ії визначали в 10-25\% випадків В-ХЛЛ [11]. Частота виявлення трисомії хромосоми 12 за допомогою FISH становить 10-16\% [19]. У ряді випадків визначається часткова трисомія, тобто дуплікація ділянки довгого плеча хромосоми 12. Мінімальним сегментом, що дуплікується, вважається область 12q13-q15, в якій виявлені гени 3 онкогенним потенціалом, проте роль жодного з цих генів в патогенезі ВХЛЛ не визначена [20]. Спочатку у хворих на В-ХЛЛ з трисомією 12 була виявлена низька тривалість життя [20]. У подальших дослідженнях незалежне несприятливе прогностичне значення даної аберації не підтвердилося. Ряд FISH-досліджень виявив, що трисомія хромосоми 12 часто буває у хворих на В-ХЛЛ з атиповою морфологією лімфоцитів (вакуолізація цитоплазми, розсічені ядра), що супроводжується атиповим імунофенотипом $\left(\mathrm{CD} 5, \mathrm{FMC7}^{+}\right)$і високою концентрацією поверхневих імуноглобулінів). У більшості сучасних цитогенетичних досліджень В-ХЛЛ прогноз для пацієнтів 3 трисомією хромосоми 12 характеризується як «проміжний» $[18,20]$. Трисомія хромосоми 12 в поєднанні з делецією 11q22-23 або 17p13 характеризується несприятливим прогнозом [19]. У хворих з трисомією хромосоми 12 практично однаково часто зустрічається як мутований, так і немутований варіант генів VH. Цей факт також дає підставу вважати прогноз для таких хворих як «проміжний» $[5,20]$. Виявлено, що ця аберація достовірно частіше зустрічається у хворих з пухлинною формою В-ХЛЛ .

Частота виявлення делеції 11q22-q23 у хворих на В-ХЛЛ коливається в межах 11-25 \% [3]. При молекулярно-біологічному дослідженні у хворих на В-ХЛЛ з делецією 11q23 були виявлені зменшення експресії білка атаксії телеангіектазії (АТM), а також інактивація АТМ в результаті делеції або мутації. Білок АТМ бере участь в різних біохімічних процесах, пов'язаних з ідентифікацією та відновленням ушкоджень ДНК, контролюючи тим самим клітинні процеси, такі як регуляція клітинного циклу і запрограмована клітинна загибель - апоптоз. Білок АТМ є «датчиком» i відноситься до класу ФІЗК-білків (Фосфатидилінозит-3-ОН-кіназа), відіграє важливу роль в передачі сигналів. Ця протеїнкіназа $є$ стимулятором захисних механізмів, які відповідальні за відновлення двохланцюгової ДНК, і одночасно зупиняє клітинний цикл в точках звірки G1 i G2. Таким чином, інактивація АТМ призводить до придушення апоптозу і зняття 
заборони на розподіл пухлинних клітин. Вперше зв'язок делеції 11q 3 більш агресивним перебігом В-ХЛЛ було виявлено ще в роботах 3 використанням стандартної цитогенетичної методики [11]. Хворі $з$ делецією 11q характеризуються швидким прогресуванням хвороби і короткою тривалістю життя. Несприятливий прогноз хворих 3 делецією 11q підтверджений багатьма незалежними дослідницькими групами $[18,19]$.

Результати нашого дослідження також показали, що різноманітність генетичних змін клітин при В-ХЛЛ обумовлює особливості перебігу захворювання.

\section{Висновки}

Молекулярно-генетичні маркери є незалежними прогностичними чинниками при В-ХЛЛ, котрі необхідно досліджувати через їхній вплив на перебіг захворювання. При наявності делеції 11q спостерігалася пухлинна форма В-ХЛЛ у вигляді генералізованої лімфаденопатії з формуванням великих конгломератів периферичних, внутрішньогрудних i абдомінальних лімфовузлів. При пухлинній формі В-ХЛЛ у більшості випадків виявлялася делеція 11q23, трисомія хромосоми 12 - достовірно частіше, ніж при інших формах В-ХЛЛ, а делеція 13q14 - ніколи, незважаючи на те, що дана генетична аномалія є найрасповсюднішою при В-ХЛЛ. Визначення одиночної делеції 13q не призводило до будь-яких клінічних особливостей перебігу В-ХЛЛ. Наші спостереження не виявили зв'язку наявності трисомії хромосоми 12 з притаманним для цієї аномалії вторинними злоякісними новоутвореннями гематологічної та негематологічної природи.

\section{Література}

1. Oscier D., Fegan C., Hillmen P., et al. Guidelines on the diagnosis and management of chronic lymphocytic leukemia. Br J Haematol 2004; 125: 294-317.

2. Caligaris-Cappio F., Hamblin TJ B-cell chronic lymphocytic leukemia: a bird of different feather. J Clin Oncol 1999; 17: 399-412.

3. Dewald GW, Brockman SR, Paternoster S.F. et al. Chromosome anomalies detected by interphase fluorescence in situ hybridization: correlation with significant biological

\section{References}

1. Oscier D., Fegan C., Hillmen P., et al. Guidelines on the diagnosis and management of chronic lymphocytic leukemia. Br J Haematol 2004; 125: 294-317.

2. Caligaris-Cappio F., Hamblin TJ B-cell chronic lymphocytic leukemia: a bird of different feather. J Clin Oncol 1999; 17: 399-412.

3. Dewald GW, Brockman SR, Paternoster S.F. et al. Chromosome anomalies detected by interphase fluorescence in situ hybridization: correlation with significant biologi- 
features of B-cell chronic lymphocytic leukaemia. Br J Haematol 2003; 121: 287-95.

4. Никитин Е.А., Лорие Ю.Ю., Меликян А.Л. и др. Факторы неблагоприятного прогноза у больных хроническим лимфолейкозом: ретроспективный анализ 206 случаев. Tep apx 2002; (7): 45-57.

5. Seiler T., Dohner H., Stingelbauer S. Risk stratification in Chronic Lymphocytic Leukemia. Semin Oncol 2006; 33: 186-94.

6. Dreger P., Stilgenbauer S., Benner A., et al. The prognostic impact of autologous stem cell transplantation in patients with chronic lymphocytic leukemia: a risk-matched analysis based on the $\mathrm{VH}$ gene mutational status. Blood 2004; 103: 2850-8.

7. Stilgenbauer S., Lichter P., Dohner H. Genetic features of B-cell chronic lymphocytic leukemia. Rev Clin Exp Hematol 2000; 4 (1): 48-72.

8. Juliusson G., Oscier D., Gahrton G. For the International Working Party on Chromosomes in CLL (IWCCLL). Cytogenetic findings and survival in B-cell chronic lymphocytic leukemia. Second IWCCCL compilation of data of 662 patients. Leuk Lymphoma 1991; 5: 21-5.

9. Autio K., Elonen E., Teerenbovi L., et al. Cytogenetic and immunologic characterizationof mitotic cells in chronic lymphocytic leukemia. Eur J Haematol 1986; 39: 289-98.

10. Захарова А.І., Обухова Т.М., Лорие Ю.Ю. и др. Цитогенетические нарушения при хроническом В-клеточном лимфолейкозе и их связь с клинико-биологическими особенностями и прогнозом заболевания. Тер арх 2006; (7): 57-62. cal features of B-cell chronic lymphocytic leukaemia. Br J Haematol 2003; 121: 287-95.

4. Nikitin E.A., Lorye Yu.Yu., Melikian A.L. ta in. Faktory nespryiatlyvoho prohnozu u khvorykh na khronichnyi limfoleikoz: retrospektyvnyi analiz 206 vypadkiv. Ter arkh 2002; (7): 45-57.

5. Seiler T., Dohner H., Stingelbauer S. Risk stratification in Chronic Lymphocytic Leukemia. Semin Oncol 2006; 33: 186-94.

6. Dreger P., Stilgenbauer S., Benner A., et al. The prognostic impact of autologous stem cell transplantation in patients with chronic lymphocytic leukemia: a risk-matched analysis based on the $\mathrm{VH}$ gene mutational status. Blood 2004; 103: 2850-8.

7. Stilgenbauer S., Lichter P., Dohner $\mathrm{H}$. Genetic features of B-cell chronic lymphocytic leukemia. Rev Clin Exp Hematol 2000; 4 (1): 48-72.

8. Juliusson G., Oscier D., Gahrton G. For the International Working Party on Chromosomes in CLL (IWCCLL). Cytogenetic findings and survival in B-cell chronic lymphocytic leukemia. Second IWCCCL compilation of data of 662 patients. Leuk Lymphoma 1991; 5: 21-5.

9. Autio K., Elonen E., Teerenbovi L., et al. Cytogenetic and immunologic characterizationof mitotic cells in chronic lymphocytic leukemia. Eur J Haematol 1986; 39: 289-98.

10. Zakharova A.I., Obukhova T.M., Lorye Yu.Yu. ta in. Tsytohenetychni porushennia pry khronichnomu Bklitynnomu limfoleikozi i yikh zviazok z kliniko-biolohichnymy osoblyvostiamy i prohnozom zakhvoriuvannia. Ter arkh 2006; (7): 57-62. 
11. Mittal A.K., Hegde G.V., Aoun P., et al. Molecular basis of aggressive disease in chronic lymphocytic leukemia patients with 11q deletion and trisomy 12 chromosomal abnormalities. Int J Mol Med. 2007;20(4): 461-9.

12. Migliazza A., Bosch F., Komatsu H., et. al. Cloning and gene mapping of the chromosome $13 \mathrm{q} 14$ region deleted in chronic lymphocytic leukemia. Genomics 1997; 42: 36977.

13. Stingelbauer S., Dohner H., BulgayMorschel M., et al. High frequency of monoallelic retinoblastoma gene deletion in B-cell chronic lymphocytic leukemia shown by interfase cytogenetics. Blood 1993; 81: 2118 24.

14. Devilder M., Francois S., Bosic C., et al. Deletion cartography around the D13S25 locus in B cell chronic lymphocytic leukemia and accurate mapping of the involved tumor suppressor gene. Cancer Res 1995; 55(6): 11355-57.

15. Bullrich F., Veronese M., Kitada S., et al. Minimal region of loss at 13q14 in B-cell chronic lymphocytic leukemia. Blood 1996; 88: 3109-15.C

16. Fegan C. Molecular abnormalities in B-cell chronic lymphocytic leukaemia. Clin Lab Haematol 2001; 23(3): 139-48.

17. Juliusson G., Oscier D., Fitchett M., et al. Prognostic subgroups in B-cell chronic lymphocytic leukemia defined by specific chromosomal abnormalities. N Engl J Med 1990; 323: 720-4.

18. Dohner H., Stingelbauer S., Benner A., et al. Genomic aberrations and sur-
11. Mittal A.K., Hegde G.V., Aoun P., et al. Molecular basis of aggressive disease in chronic lymphocytic leukemia patients with $11 \mathrm{q}$ deletion and trisomy 12 chromosomal abnormalities. Int J Mol Med. 2007;20(4): 461-9.

12. Migliazza A., Bosch F., Komatsu H., et. al. Cloning and gene mapping of the chromosome $13 \mathrm{q} 14$ region deleted in chronic lymphocytic leukemia. Genomics 1997; 42: 36977.

13. Stingelbauer S., Dohner H., BulgayMorschel M., et al. High frequency of monoallelic retinoblastoma gene deletion in B-cell chronic lymphocytic leukemia shown by interfase cytogenetics. Blood 1993; 81: 2118 24.

14. Devilder M., Francois S., Bosic C., et al. Deletion cartography around the D13S25 locus in B cell chronic lymphocytic leukemia and accurate mapping of the involved tumor suppressor gene. Cancer Res 1995; 55(6): 11355-57.

15. Bullrich F., Veronese M., Kitada S. et al. Minimal region of loss at 13 q14 in B-cell chronic lymphocytic leukemia. Blood 1996; 88: 31093115 .

16. Fegan C. Molecular abnormalities in B-cell chronic lymphocytic leukaemia. Clin Lab Haematol 2001; 23 (3): 139-48.

17. Juliusson G., Oscier D., Fitchett M., et al. Prognostic subgroups in B-cell chronic lymphocytic leukemia defined by specific chromosomal abnormalities. N Engl J Med 1990; 323: 720-4.

18. Dohner H., Stingelbauer S., Benner A., et al. Genomic aberrations and sur- 
vival in chronic lymphocytic leukemia. N Engl J Med 2000; 343: 1910-6.

19. Stilgenbauer S., Dohner H. Molecular genetics and its clinical relevance. Hematol Oncol Clin North Am 2004; 18: 827-48.

20. Dierlamm J., Wiodarska I., Michaux L., et al. FISH identifies different types of duplications with 12q13-15 as the commonly involved segment in B-cell lymphoproliferative malignancies characterized by partial trisomy 12. Genes Chromosomes Cancer 1997; 20 (2): 155-66. vival in chronic lymphocytic leukemia. N Engl J Med 2000; 343: 1910-6.

19. Stilgenbauer S., Dohner H. Molecular genetics and its clinical relevance. Hematol Oncol Clin North Am 2004; 18: 827-48.

20. Dierlamm J., Wiodarska I., Michaux L. Et al. FISH identifies different types of duplications with 12q13-15 as the commonly involved segment in B-cell lymphoproliferative malignnancies characterized by partial trisomy 12. Genes Chromosomes Cancer 1997; 20 (2): 155-166.

Стаття надійшла 16.08.2021

Контакти: perekhrestenko.tanya@gmail.com 